\title{
Quality Assurance of Higher Education in Russia and Its Enlightenment on Our Country
}

\author{
Lirong Song \\ Heihe University \\ Heihe, China 164300
}

\author{
Shuwu Wang \\ Heihe University \\ Heihe, China 164300
}

\author{
Wei Xu \\ Heihe University \\ Heihe, China 164300
}

\begin{abstract}
After collapse of the Soviet Union, Russia carries out a series of economic reform. Under the condition of market economy, great changes also have occurred in colleges. This article describes changes happened in higher education and some measures to assure the quality of higher education, in order to have reference significance on development of higher education in our country.
\end{abstract}

Keywords-Russia; higher education; quality assurance; enlightenment

\section{CURRENT SituAtion AND Changes OF Higher EDUCATION IN RUSSIA}

Since the 1990s, Russia has begun to step on the road of marketization. The parliament in Russia formulates laws and regulations such as Denationalization of Enterprises and Basic Principle of Privatization, Law of Privatization of National and Municipal Enterprises in Russian Federation, to accelerate the progress of privatization of the country. The transformation of economy promotes the development of education in Russia, especially the rise of non-state education. One of the problems caused by rapid increase of number of self-supporting students is that double standard may let a large number of unqualified students enter colleges and cause quality reduction of higher education. In other words, double admission standard exchanges funding for higher education at the cost of sacrificing high quality, which greatly weaken the social choice function of colleges. On a long view, the loss outweighs the gain.

Just as the transition from higher education to ranking system (four years of bachelor and two years of master), it simultaneously divides the existing universities into national university, state university and other universities. Only the former two kinds of universities can get national financial allocation. Most of other universities will not get budget

Fund program: This article is the research result of Internal Governance Struc ture Research in Universities in Russia (12E126), the philosophy and social s ciences planning project in Heilongiang province; the research result (GJE12 14021) of Comparative Study on Quality Assurance System of Higher Educat ion in China and Russia, special topic on base of the twelfth five-

year plan about science of education in Heilongjiang province; Research on $\mathrm{T}$ eaching Management System Practice in China-

Russia Cooperation in Running Schools (JGZ201201193), funding results of $r$ eform pilot program in new century teaching reform project. allocation. In the framework of this act, it plans to transfer most of the universities from the management of federation to local place. Therefore, leaders of many universities try to adopt the way of college merger to hold the position to get national financial allocation. It appears the wave that ordinary universities actively request to be merged by national university or state university.

On one hand, various universities construct branch schools and blindly expand in order to win over source of students and income. It is impossible to completely avoid reducing the number of college students and teachers after the merger. Because they only pay attention to enrolling students and charging fees, attach no importance to construction of educational facilities and cultivation of teaching staff, some branch schools of colleges are warn to be "closed" because they have poor school-running conditions and cannot reaching requirements of education quality. On the other hand, it is also very difficult for universities that lose the support of national finance to survive. This shows that the purpose of increasing enrollment and merging of colleges is not to seek for development but for survival. The reform in higher education field in Russia doesn't have deep consideration but have some blindness.

The continuous expansion of social requirements for diversification of higher education forms enormous pressure on higher education. The government invests inadequate funding for higher education, which cannot fulfill expectations of mass of students to go to colleges. Under the circumstances, in order to ease the contradiction of inadequate funds in universities and improve resource utilization rate and competitiveness of colleges, at present, in Russia, except for military academies, colleges implement the system of multiple founders, instead of school-running system that take the state as the single main body. This system brings organs of state power, local organs of self-government, domestic and foreign enterprises and organs with various forms of ownership, all kinds of social organizations and religious groups that have registered and citizens in Russia and other countries in the possible range of college founders. This system has been put into practice immediately since Education Act of Russian 
Federation was issued in 1992. It was affirmed clearly again in Education Act of Russian Federation, which was modified in 1996.

\section{ORDERLY COMPETITION AND QUALITY ASSURANCE OF HIGHER EDUCATION UNDER MARKET MECHANISM}

The market-driven competition of higher education and changes happened inside colleges make Russian society put forward the quality assurance of higher education. In that way, how Russia can assure the quality of higher education under the condition of market economy? Generally speaking, it mainly has the following aspects:

\section{A. Increase Financial Fund and Improve Competitiveness of Material Technology}

In order to adapt to conditions of market economy, colleges need to establish stable finance system of multi-channels. As national and regional science, culture and education center, colleges further implement information and new technology education. It decides development prospect of universities to a large extent and competitiveness in the perspective of society and government, popularity degree and authority. In all development strategies of colleges in Russia, compared with other expenditures, information technology has more financial advantages. For colleges in Russia, the capitals to carry out the plan of information technology mainly derive from internal budget. Therefore, they always have enormous investments. The "Unified Information Network" that is establishing in Russia tries to widely apply information technology to improve the cultivation quality of professional talents in Russia and ensure informatization of the whole people.

\section{B. Strictly Control the Application for Establishment of Colleges and Manage Branch Schools}

Russia implements strict management for branch schools of colleges. Some colleges in Russia establish many branch schools outside the main campus for the sake of economic interests. It reduces the quality of teaching and influences reputation of higher education in Russia. So education departments in Russia begin to check and reorganize colleges and improve the requirements for school running at the same time. Therefore, if branch schools cannot keep the level that the quality of education should have, both branch schools and main campus will be threatened to "be closed". It will urge colleges to effectively supervise teaching plan of branch schools. [1]

\section{Examination and Approval of Educational Institutions in Russia and Supervision and Assessment System for Education Quality}

In order to guarantee the education quality of colleges and strengthen the management and control for educational institutions, Russia gradually establishes policies to appraise and elect key universities and innovative universities and evaluate regular institutions of higher learning in legal form. This policy is formed by three continuous procedures, namely approval, assessment and identification of the state on colleges. The most important item is to implement the system of license for running a school. The Ministry of Education and Science and Scientific Supervision Department shall be responsible to examine, approve and assess institution of higher learning and establish specialized appraisal committee. This committee does not belong to any organization. In order to make the evaluation independent and fair, the appraisal committee shall be formed by representative of national institute of education, representative of local education agency, members in Committee of Vice Chancellors and Principals and experts in education field.

1) For the qualification examination and approval of educational (school-running) institutions, appraisal committee evaluates units that apply for running a school: Schools can carry out education (school-running) activities after passing the examination and approval and getting the license for running a school. Meanwhile, they can enjoy financing or privilege provided by the government according to provisions of law. The Ministry of Education and Science in Russian Federation and regional education management organizations can handle education (school-running) license. The duration of education (school-running) license shall be no less than three years.

2) 2. Supervision, assessment and appraisal of quality of education: Government of the Russian Federation stipulates that the assessment and appraisal of newly-built teaching institutions will be carried out after they cultivate the first session of graduates. The assessment and appraisal for all institutions of higher learning will be implemented every five years. The law of Russia stipulates that the assessment and appraisal is the main form for the state to check education quality of educational institutions. It is implemented by the assessment and appraisal committee. The procedures of assessment and appraisal include: internal self-assessment of educational institutions, external assessment identification and the issue of assessment and appraisal result. The contents of assessment and appraisal include: teaching form and content, level; matching degree of cultivation quality of students and national education standards; before the assessment and appraisal, the number of graduates who smoothly pass the total appraisal within three years continuously exceeds $50 \%$. "National confirmation" is the last hurdle in affirming schoolrunning qualification. It bases on the decision of assessment and appraisal committee, lists educational (school-running) institutions in a certain category and determines the level. Once schools get national affirmation and rating certificate of affirmation, they have the right to issue state-certified graduation certificate to graduates. The period of validity of affirmation certificate is five years. After five years, schools need to reacquire recognition of the state through reexamination so that they can continue to issue relevant diploma. [2] 


\section{THINKING}

\section{A. Establish Relatively High Level of Laws and Regulations of Evaluation on Colleges}

Russia uses the form of Education Act to establish verification system of higher education. At the same time, it also introduces a series of special laws and regulations, such as Education Activity Recognition Rules (2000), National Appraisal Regulations in Colleges (1999) and National Assessment Regulations in Colleges.

In comparison, in our country, there are few laws and regulations directly related to evaluation of colleges. Interim Provisions for Educational Assessment of General Institutes of Higher Education is an important regulation to standardize evaluation on institutions of higher learning in our country at present. But meanwhile, it is also a kind of administrative laws and regulations at the lowest level. It has many aspects that do not conform to the current reform of higher education. For example, it emphasizes oneness of evaluation subject and attaches inadequate importance to social assessment. These problems need to be solved in the process of upgrade of laws and regulations. Besides, phenomenon such as blindly pursues upgrade and expansion of colleges and declination of teaching quality exist in colleges of our country. It not only wastes a lot of money, but also cannot help colleges to highlight characteristics; because teachers put inadequate energy and the investment of education funds is insufficient, the quality of teaching in colleges also face serious situation. The basic school-running conditions in many schools cannot meet national requirements. They cannot guarantee the basic quality of teaching. The above questions have relationship with the situation that the evaluation policy in colleges of our country is unsound or imperfect to a large extent.

Because the form of social system in institutional economics has the characteristics of "path dependence", effective system design needs to consider the influence of factors such as society, politics, economy and culture of the nation. Therefore, in the research and practice of evaluation of colleges, our country shall gradually make the regulation of Interim Provisions at low level rise to Regulations of Education Evaluation of General Institutes of Higher Learning, to make it become administrative regulation or national legislation at high level. In formulating high level of evaluation system of colleges, our country shall make evaluation system have completeness and operability. Completeness refers to complete system. All assessment activities have specific requirements and regulations; Operability means the evaluation procedure is simple and easy to run. Legalization represents the development level of higher education evaluation of a country. Therefore, our country shall accelerate the legalization process of evaluation of higher education institutions, continuously improve evaluation policy of colleges in our country, and further standardize evaluation activity of colleges in our country, to make it have rules to follow and guarantee the quality of evaluation on colleges. [3]

\section{B. Further Establish Correct Quality View of Higher Education}

The market-driven competition of higher education in Russia and changes happened in college prompt Russian society to put forward the quality assurance of higher education. In order to solve this problem, education and science supervision bureau in Russian Federation closes some branch schools of national universities and private universities that cannot achieve the standard of education quality. Since September 2004, Russia has begun to forbid colleges to open branch schools and carry out major inspection of education quality of existing colleges. After unqualified branch schools are close, students are arranged to other universities to continue to study. In comprehensively implementing quality evaluation of higher education, Russian Federation carry out reforms that aim at improving comprehensive competitiveness of institutions of higher learning, which mainly include improving the treatment of teachers, strengthening technical equipment in institutions of higher learning and establishing internal competition system of higher education. In order to ensure the development of higher education and improve education quality, according to specific circumstances, mainly divide universities in Russia into four types, namely research university, teaching university, service university and careeroriented university and adopt corresponding development patterns.

Just as Russia, our country is also in the transition period that transforms from planned economy to market economy. Under the condition of socialist marketing economy, the key point of management system reform of higher education in our country is to break the situation that is highly centralized, includes too many aspects, has rigid and excessive control as well as barriers between higher and lower levels and constructs repeatedly. In recent years, our country adopts the ways of "co-construction, adjustment, cooperation and merger" to adjust management system of institutions of higher learning. Most schools managed by central ministries and commissions originally have been delegated to local governments to manage or merged with other schools. Specialty structure, type structure and hierarchical structure of higher education are also adjusted according to requirements of economy and society. Because higher education at various levels is different in various regions, in the management process, it is necessary to pay attention to giving different guidance to different categories, according to higher education of different types, put forward different standards and ensure quality requirements that various schools shall have. Breakthrough of management system reform of higher education creates new space to improve education quality. Following the guidelines of quality, scale, structure, benefit and coordinated development is the true development view as well as the healthy and mature quality view.

The development of higher education shall center on improving the quality, practically strengthen the management and strive to highlight characteristics. Colleges and relevant functional departments shall have strong awareness to create and preserve their reputation in running schools and the quality of the brand and continuously improve quality of education through the running of effective mechanisms such as self- 
examination, government inspection, social evaluation and market supervision.

\section{REFERENCES}

[1] Bai Meiling, Deng Zhiwei. Russis Constructs New System of Higher Education [J], the Science Education Article Collects, 2005, 1

[2] Gao Lvqi. Higher Education in Russia and Its Changes [J], Journal of Kunming University of Science and Technology (Social Science Edition), 2006, 6(1)

[3] Sun Mingjuan. Verification System of Higher Education in Russia and Its Enlightenment [J], China Education Study, 2006, 3 (5) 